\title{
INCIDENCE OF Listeria monocytogenes AND Bacillus cereus IN SOME FOOD OF PLANT ORIGIN AND METHODS OF THEIR CONTROL
}

Radwan, U. M. M. ${ }^{1}$; Gihan M. El Moghazy ${ }^{2}$ and M. F. Abd El-Aziz ${ }^{2}$

1- Institute of Environmental Studies and Res., Ain Shams University.

2- Regional Center for Food and Feed (RCFF) - Agriculture Research Center (ARC).

\begin{abstract}
This study was carried out to develop a practical and effective method for inhibition or reduction of the growth of Listeria monocytogenes and Bacillus cereus counts on orange, guava, carrot and green beans at different temperatures: room temperature $25^{\circ} \mathrm{C} \pm 1$, refrigerator temperature $4^{\circ} \mathrm{C} \pm 2$ and freezer temperature $-18^{\circ} \mathrm{C}$ for different storage periods $(0,1,3,7,30,60,120$ and 180 days). Also screening of the presence of these 2 microorganisms was performed using RT-PCR technique. All samples were spot-inoculated with the pathogenic strains $6 \log _{10} \mathrm{cfu}$ near the stem end and were submerged in two solutions of distilled water containing $1.5 \%$ for each of Lactic acid and hydrogen Peroxide (solution A) and 1.5\%: $2.0 \%$ (solution B) respectively at $40^{\circ} \mathrm{C}$ for $15 \mathrm{~min}$. Inoculated samples treated with sterile distilled water at the same temperatures and for the same durations were considered as controls. Listeria monocytogenes and Bacillus cereus were detected in $6.67 \%$ and $13.33 \%$ of the examined samples, respectively. The results showed that, bacteria on all treated samples except the green beans samples were completely inhibited by treatment with solution A from the first day of the experiment. Although the injured bacteria were still present till the $1^{\text {st }}$ day for Guava and the $3^{\text {rd }}$ day for carrot, all treatments didn't affect the injured bacteria in case of green beans samples till the end of the experiment (at all treated temperatures). Similar trends were found for solution B treated samples (orange, guava, carrot and green beans).
\end{abstract}

\section{INTRODUCTION}

Food poisoning cases caused by contamination of vegetables and fruits have been reported in the last decade. Listeria monocytogenes is considered as one of the most important causes of food poisoning which are characterized by nausea, vomiting, fever, abdominal pain and diarrhea. The complications of the infection with this pathogen are meningitis, faetal malformation, mental retardation and abortion of pregnant women.

Listeria monocytogenes can be isolated from soil, water, animal manure and other environmental sources. Vegetables can become contaminated from the soil or from manure used as fertilizer. The bacterium has been found in a variety of raw foods such as vegetables, fruits, ready-toeat food, uncooked meat and vegetables, as well as in post contaminated processed foods (Farber and Peterkin, 1991; Lou and Yousef, 1996).

Some countries have established legal limits on the number of Listeria monocytogenes organisms that are permissible in foods, especially ready-to-eat products, whereas others have suggested guidelines or criteria that do not have legal standing (Jay, 1996). 
The International Commission on Microbiological Specification for Foods has come to the conclusion that if this organism does not exceed 100 organisms $/ \mathrm{g}$ of food at the point of consumption, the food is considered acceptable for individuals who are not at risk.

Guidelines for some ready to-eat foods establish four quality groups based on the numbers of Listeria monocytogenes: not detected in $25 \mathrm{~g}$ is satisfactory; $<10^{2} / 25 \mathrm{~g}$ is fairly satisfactory; $10^{2}$ to $10^{3}$ is unsatisfactory; and numbers of $>10^{3}$ make the food product unacceptable (Gilbert, 1992).

Another important pathogen shares Listeria monocytogenes in its food poisoning effect is Bacillus cereus which causes the same gastro enteric symptoms with its excreted toxins.

Bacillus cereus is a food-borne pathogen which often contaminates foods of plant origin. Recent investigations have shown that, members of the Bacillus cereus group carry genes which have the potential to cause gastrointestinal and somatic diseases mainly because of its produced exotoxins (Hansen et al., 2002).

The epidemiology of Bacillus cereus strains responsible for food poisoning is scantly known, mostly because the genotypic and toxigenic properties of the Bacillus cereus strains isolated during food-poisoning outbreaks have been never catalogued (Ghelardi et al., 2002).

Improving methods for detection of food poisoning microorganisms in food stuffs plays a very important role in its control. DNA-based methods, such as the PCR, have been increasingly used for rapid, sensitive, and specific detection of Listeria monocytogenes (Deener and Boychus, 1991; Olsen et al., 1995; Francis and O'Beirne, 2006) and Bacillus cereus (Choo et al. 2007; and Abriouel et al. 2007, and Masafumi et al., 2006).

The demand of vegetables minimally processed (ready-to-use) has increased partly due to the frequent use of the food services, where the salads are always included in the daily menus (de Curtis et al., 2002). Fresh fruits and vegetables generally do not undergo any processing or cooking to eliminate pathogenic microorganisms before consumption. Therefore, methods to effectively reduce or eliminate pathogenic microorganisms on fruits and vegetables are needed. Currently, there is no processing method that will totally inactivate pathogens on fresh products without compromising sensory quality (Venkitanarayanan et al., 2002).

The Food and Drug Administration proposed that treatments of fruits, vegetables, and commercial fresh juices should be capable of reducing pathogen loads by a minimum of 5.0 log CFU (FDA, 1998).

Washing with cold chlorinated water is the most widely used method, but its efficacy in inactivating pathogenic bacteria on the surfaces of fresh products is minimal (Sapers and Simmons 1998 and Sapers et al., 1999).

Lactic acid and hydrogen peroxide are generally recognized as safe chemicals for specific uses in foods. The antibacterial activity of hydrogen peroxide alone or in combination with lactic acid on fresh products has been reported (Venkitanarayanan et al., 1999; Sapers et al., 2000).

Hence, the treatment of fruits and vegetables with hydrogen peroxide with or without lactic acid may be a practical approach to inactivate 
pathogenic bacteria without compromising sensory quality (Chia-Min Lin, 2002).

The aim of this work is to use different technological treatments for controlling the spread of Listeria monocytogenes and Bacillus cereus through:

1- Screening of the incidence of Listeria monocytogenes and Bacillus cereus in carrots, green beans, guava and orange using real time PCR technique.

2- Using low temperature treatment at $\left(5^{\circ} \mathrm{C}\right.$ and $\left.-18^{\circ} \mathrm{C}\right)$ for different storage periods and studying their effect on the above mentioned pathogens.

3- Using different concentrations of lactic acid and hydrogen peroxide as surface preservatives and studying their effect on the above mentioned pathogens.

\section{MATERIALSAND METHODS}

\section{A- Materials}

Samples: Sixty samples of fresh vegetables and fruits (orange, guava, green beans and carrots) were purchased and collected from different Egyptian retail markets in (Giza, Misr Al-Qadima, Nasr city, Imbaba and Maadi) in different seasons to detect Listeria monocytogenes and Bacillus cereus by Real Time Polymerase Chain Reaction (RT-PCR) as a rapid test. Samples were collected in ice box, were labeled with all required data (Date of Collection, Source.... Etc") and were transported immediately to the laboratory. Also about $15 \mathrm{~kg}$ from each of the examined types (orange, guava, green beans and carrots) were collected to study the factors affecting the growth of Listeria monocytogenes and Bacillus cereus in different storage conditions after treatment with Lactic acid (LA) and Hydrogen peroxides $\left(\mathrm{H}_{2} \mathrm{O}_{2}\right)$ at different concentrations and different temperatures.

Bacterial strains: The bacterial strains (Listeria monocytogenes and Bacillus cereus) were isolated, identified and kindly supplied by Food safety and Biotechnology Lab - Regional Center for Food and Feed - Agriculture Research Center - Egypt.

DNA extraction buffer: DNA extraction was performed using Prepman Ultra sample preparation reagent, Applied Biosystem, USA.

Primers and probe: Sequences of primers and probe used in this study are illustrated in table (1).

Table (1): Primer and Probe sequences of bacteria under investigation:

\begin{tabular}{|l|l|}
\hline $\begin{array}{l}\text { Listeria monocytogenes Forward } \\
\text { primer sequence: }\end{array}$ & TGC AAG TCC TAA GAC GCCA \\
\hline $\begin{array}{l}\text { Listeria monocytogenes Reverse } \\
\text { primer sequence: }\end{array}$ & CAC TGC ATC TCC GTG GTA TAC TAA \\
\hline Listeria monocytogenes Probe: & $\begin{array}{l}\text { 6 - FAM - CGA TTT CAT CCG CGT GTT } \\
\text { TCT TTT CG - TAMRA }\end{array}$ \\
\hline $\begin{array}{l}\text { Bacillus cereus Forward primer } \\
\text { sequence: }\end{array}$ & GTG TTT GAC CAA GGT GGA CAA \\
\hline
\end{tabular}


Radwan, U. M. M. et al.

\begin{tabular}{|l|l|}
\hline $\begin{array}{l}\text { Bacillus cereus Reverse primer } \\
\text { sequence: }\end{array}$ & TTA CTC CAT AGA GCA CCC TTG GA \\
\hline Bacillus cereus Probe: & $\begin{array}{l}\text { 6 - FAM- CCA AAA CCA GTT GCC AGT } \\
\text { GCA TTG G - TAMRA }\end{array}$ \\
\hline
\end{tabular}

Master Mix: TaqMan Universal Master Mix (Applied Biosystems, USA) which contained AmpErase uracil-N-glycosylase (UNG), deoxynucleoside triphosphate with dUTPs, 6-carboxyrhodamine as an internal passive fluorogenic reference, and an optimized buffer component.

Mixture (B): Prepared 1.5/1.5 \% vol/vol from Lactic acid (LA) and Hydrogen peroxides (H2O2), containing to 1 litre of distilled water.

Mixture (C: Prepared 1.5/2.0 \% vol/vol from Lactic acid (LA) and Hydrogen peroxides $(\mathrm{H} 2 \mathrm{O} 2)$, containing to 1 litre of distilled water.

All concentrations were prepared fresh at the time of work.

\section{B- Methods}

\section{Screening of Listeria monocytogenes and Bacillus cereus in examined samples:}

Preenrichment: All tested samples were enriched in Buffered Peptone Water (BPW) for 24 hours at $37^{\circ} \mathrm{C}$ before subjected to DNA extraction.

DNA extraction: DNA extraction was performed using Prepman Ultra sample preparation reagent, Applied Biosystem, USA, according to the user manual attached to the Kit as follows:

One $\mathrm{ml}$ from the enriched BPW was transferred to $2 \mathrm{ml}$ microcentrifuge tube and spinned for 3 minutes at $16000 \mathrm{rpm}$. The resulted supernatant was discarded and the obtained pellet was eluted using $200 \mathrm{ul}$ of Prepman Ultra sample preparation reagent. The tube then was incubated in a boiling water bath for 10 minutes with frequent mixing. After reaching room temperature, the tube was centrifuged at $16000 \mathrm{rpm}$ for 3 minutes then $50 \mathrm{ul}$ from the supernatant was transferred to a new labeled microcentrifuge tube and stored at $-4{ }^{\circ} \mathrm{C}$ till PCR reaction.

PCR reaction: PCR was performed in a reaction mixture with a total volume of $25 \mathrm{ul}$ containing $1 \mathrm{ul}$ of extracted DNA, $0.5 \mathrm{mM}$ of the same primers of each pathogen, $0.2 \mathrm{mM}$ of fluorogenic probe ( Table 22), and TaqMan Universal Master Mix (Applied Biosystems, USA). The Master Mix contained AmpErase uracil- $N$-glycosylase (UNG), deoxynucleoside triphosphate with dUTPs, 6-carboxyrhodamine as an internal passive fluorogenic reference, and an optimized buffer component. Amplification and detection were carried out in optical-grade 96-well plates in an ABI Prism 7000 sequence detection system (Applied Biosystems) with an initial step of $50^{\circ} \mathrm{C}$ for 2 minutes, which is the required optimal AmpErase UNG enzyme activity, and then at $95^{\circ} \mathrm{C}$ for 10 minutes, to activate the AmpliTaq Gold DNA polymerase and to deactivate the AmpErase UNG enzyme, followed by 40 cycles of $95^{\circ} \mathrm{C}$ for 15 second and $60^{\circ} \mathrm{C}$ for 1 minutes. The reaction conditions for amplification and the parameters for fluorescence data collection were programmed into a Dell laptop linked directly to the $A B I$ Prism 7000 sequence detection system by using the SDS 1.6 application software, according to the manufacturer's instructions. After real-time data acquisition, the threshold, which was defined 
as being 10-fold higher than the baseline, was determined; and the cycle threshold $(C T)$ value was manually set so that it intersected the amplification curves in the linear region of the semilog plot.

Studying the effect of surface treatments, storage temperatures and storage durations on viability of Listeria monocytogenes and Bacillus cereus:

\section{Samples Preparation:}

All collected samples (15 kg from each type) were washed in sterile plastic ice box with soap and rinsing tap water, and wiped with a paper towel, and then immersed in physiological saline, and wiped again with a paper towel, then washed in sterile distilled water and wiped again with a paper towel, After dryness, each type of samples was divided into 3 parts (A, B and C) and each individual unit from each part was subsequently separated into sterile stomacher bag. All bags were placed at $4{ }^{\circ} \mathrm{C}$ until the time of inoculation.

\section{Preparation of bacterial suspensions:}

Listeria monocytogenes and Bacillus cereus were inoculated in brain heart infusion broth and incubated for $24 \mathrm{hrs}$ at $30{ }^{\circ} \mathrm{C}$ and $37^{\circ} \mathrm{C}$ for Bacillus cereus and Listeria monocytogenes respectively.

The colony forming units per each milliliter of prepared suspension was estimated by using each Bacillus cereus agar and Listeria oxford agar as follows:

Sterile dilutions of the prepared suspensions were done using sterile saline solution, from each dilution $1 \mathrm{ml}$ was inoculated in sterile Petri dish then about $10 \mathrm{ml}$ of the specific media was poured and after good mixing and solidification of the media, the plates were incubated at $30^{\circ} \mathrm{C}$ and $37{ }^{\circ} \mathrm{C}$ for Bacillus cereus and Listeria monocytogenes respectively, Suspension of $10^{6}$ $\mathrm{cfu} / \mathrm{ml}$ were stored at $4{ }^{\circ} \mathrm{C}$ till inoculation.

Inoculation of samples under investigation, surface treatment by Hydrogen peroxide, Lactic acid and Water and enumeration of Listeria monocytogenes and Bacillus cereus in subsamples were performed according to (Venkitanarayanan et al., 2002)

\section{RESULTS AND DISCUSSION}

Two important criteria that should be considered in developing an antimicrobial treatment for product are that the treatment should be capable of reducing the microbial load on produce to be disinfected by at least 3 log CFU, and preferably by more than 5 log CFU and that it should not adversely affect the sensory characteristics of the treated produce (Venkitanarayana et al. 2002).

A spot inoculation method was used to inoculate samples under investigation with the pathogens because this method represents the mode by which they could be contaminated in the field by feces, soil, or hands more realistically than a dip method of inoculation. Furthermore, a spot inoculation method is the most consistent and reproducible method for inoculating a known number of bacterial cells on the surfaces of tested samples (Venkitanarayana et al. 2002). 
Radwan, U. M. M. et al.

Selective culture media can inhibit the recovery of stressed cells of bacteria. In this study, Buffered peptone water was used as a nonselective media for the 2 pathogens evaluated, and Oxford agar and Bacillus cereus agar were used as the selective media for enumerating Listeria monocytogenes and Bacillus cereus, respectively. (Venkitanarayana et al. 2002).

Data in Table 2 illustrate the incidence of Listeria monocytogenes and Bacillus cereus in collected fruits and vegetables samples. It is clear that, Listertia was detected in $6.67 \%$ of the examined samples while Bacillus cereus was detected in $13.33 \%$.

Table (2): Incidence of Listeria monocytogenes and Bacillus cereus in examined samples:

\begin{tabular}{|l|c|c|c|}
\hline & No. of samples & L. monocytogenes & B. cereus \\
\hline Carrot & 15 & 2 & 2 \\
\hline Green Beans & 15 & 1 & 1 \\
\hline Guava & 15 & - & 4 \\
\hline Orange & 15 & 1 & 1 \\
\hline Total (number) & 60 & 4 & 8 \\
\hline Total (\%) & - & 6.67 & 13.33 \\
\hline
\end{tabular}

Also the results in Figure (1) showed the amplification blot of the positive samples which is indicated by cutting the threshold line forming a characteristic curve. The curves of the 4 positive Listeria monocytogenes samples and the 8 positive Bacillus cereus samples are shown in this figure. The negative results are indicated by the noise which appears in the same figure. 


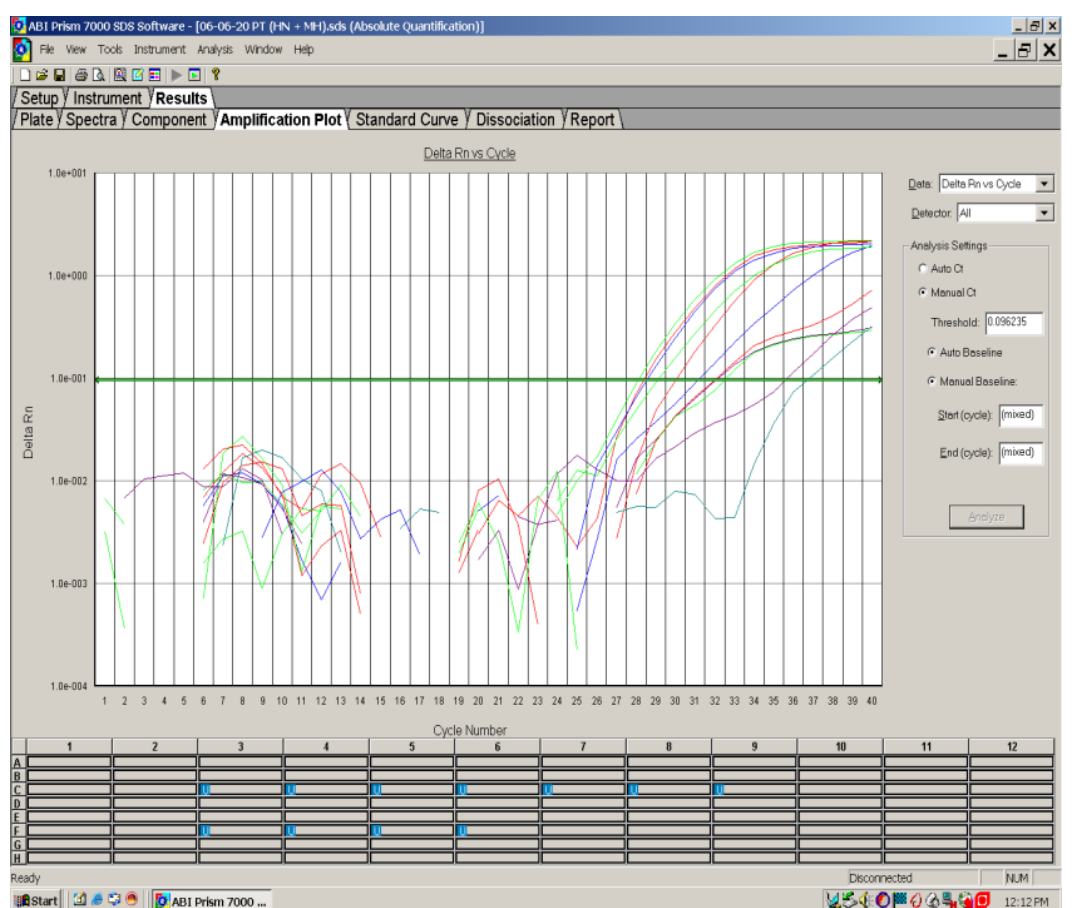

Figure (1): Amplification blots of Listeria monocytogenes and Bacillus cereus positive samples using RT-PCR.

This data represents greater level than that obtained by other authors like Sagoo et al., 2001, Abadias et al., and Froder et al., who detect Listeria monocytogenes in $1.5 \%, 0.7 \%$ and $0.6 \%$ of vegetables and fruits respectively. This difference in obtained data may be attributed to the difference in the hygienic practices which may lead to increase in the incidence of this type of bacteria.

It is clear from the obtained data that, at zero time treatment ( $B$ group) (Lactic acid : $\mathrm{H}_{2} \mathrm{O}_{2} 1.5: 1.5$ ) was sufficient to injure all Bacillus cereus and Listeria monocytogenes which is clear with their negative result in counting and positive result in detection of injured cells; while treatment (C group) (Lactic acid : $\left.\mathrm{H}_{2} \mathrm{O}_{2} 1.5: 2.0\right)$ could slightly decrease Bacillus cereus count and markedly decrease Listeria monocytogenes count. The obtained result agreed with that reported by Venkitanarayanan et al. (2002) who observed the marked reduction of Listeria monocytogenes count on the surface of some fruits and vegetables after treatment with lactic acid: $\mathrm{H}_{2} \mathrm{O}_{2}$ $1.5: 1.5$.

By the end of the $1^{\text {st }}$ week of storage, count of treated samples in (B and $C$ groups) was negative while injured Bacillus cereus bacteria were detected in (C group) treated Oranges (Table 3 ). This data are supported by that obtained by Lin et al., 2002 and Ukuku 2004 who observed the reduction of bacterial count of refrigerated fruits and vegetables treated with Lactic acid $: \mathrm{H}_{2} \mathrm{O}_{2} 1.5: 1.5$ by 3 logs. This also agrees with data obtained from tables 6,9 
and 12. The resistance of Bacillus cereus bacteria may be due to its being a sporulating pathogen which can resist the unfavorable conditions.

Table (3): Effect of different surface treatments of orange on Bacillus cereus and Listeria monocytogenes count (log) at room temperature for different storage periods and incidence of injured bacteria

\begin{tabular}{|c|c|c|c|c|c|c|c|}
\hline \multicolumn{2}{|c|}{ Orange } & \multicolumn{9}{c|}{ Room Temperature } \\
\cline { 3 - 9 } \multicolumn{2}{|c|}{} & \multicolumn{2}{c|}{ A } & \multicolumn{2}{c|}{ B } & \multicolumn{2}{c|}{ C } \\
\cline { 3 - 8 } & B.c & L.m & B.c & L.m & B.c & L.m \\
\hline \multirow{2}{*}{0 Day } & count & 6.60 & 6.60 & - & - & 3.95 & - \\
\cline { 2 - 9 } & injured & D & D & D & D & D & D \\
\hline \multirow{2}{*}{1 Day } & count & 3.48 & 2.60 & - & - & 3.30 & - \\
\cline { 2 - 9 } & injured & D & D & ND & ND & D & D \\
\hline \multirow{2}{*}{3 Day } & count & 3.38 & 2.48 & - & - & - & - \\
\cline { 2 - 9 } & injured & D & D & ND & ND & D & ND \\
\hline \multirow{2}{*}{7 Day } & count & 1.77 & 1.90 & - & - & - & - \\
\cline { 2 - 9 } & injured & D & D & ND & ND & D & ND \\
\hline
\end{tabular}

(D): detected (ND): not detected (A): Dist. Water.... (B): Lactic: $\mathrm{H}_{2} \mathrm{O}_{2}$ 1.5:1.5....(C): Lactic: $\mathrm{H}_{2} \mathrm{O}_{2}$ 1.5:2.0.... (B.c): Bacillus cereus.... (L.m): Listeria monocytogenes.

Storage at $+5 \mathrm{C}^{\circ}$ : $+8 \mathrm{C}^{\circ}$ could keep the Bacillus cereus and Listeria monocytogenes count in (A group) in relatively higher count than at room temperature. Also Bacillus cereus count in ( $\mathrm{C}$ group) treated oranges could survive longer than that at room temperature (Table 4). These findings were in accordance with that obtained by Valero (2007) who concluded that, storage of food at $4^{\circ} \mathrm{C}$ did not affect the bacterial count. This also can clarify data obtained from table 7, 10 and 13 .

Table (4): Effect of different surface treatments of orange on Bacillus cereus and Listeria monocytogenes count (log) at refrigerator ( $\left.+5 \mathrm{C}^{\circ}: \mathbf{+ 8 \mathrm { C }}-\right)$ for different storage periods and incidence of injured bacteria

\begin{tabular}{|c|c|c|c|c|c|c|c|}
\hline \multicolumn{2}{|c|}{ Orange } & \multicolumn{7}{c|}{ Refrigerator +5Co: +8Co } \\
\cline { 3 - 9 } \multicolumn{2}{|c|}{} & \multicolumn{2}{|c|}{ A } & \multicolumn{2}{|c|}{ B } & \multicolumn{2}{c|}{ C } \\
\cline { 3 - 9 } & B.c & L.m & B.c & L.m & B.c & L.m \\
\hline \multirow{2}{*}{ 0 Day } & count & 6.60 & 6.60 & - & - & 4.36 & - \\
\cline { 2 - 9 } & injured & D & D & D & D & D & D \\
\hline \multirow{2}{*}{ 1 Day } & count & 3.00 & 2.77 & - & - & 3.78 & - \\
\cline { 2 - 9 } & injured & D & D & ND & ND & D & D \\
\hline \multirow{2}{*}{3 Day } & count & 2.00 & 3.04 & - & - & 4.36 & - \\
\cline { 2 - 9 } & injured & D & D & ND & ND & D & ND \\
\hline \multirow{2}{*}{7 Day } & count & 1.95 & 3.59 & - & - & - & - \\
\cline { 2 - 9 } & injured & D & D & ND & ND & D & ND \\
\hline
\end{tabular}

Listeria monocytogenes in the non treated Oranges (A group) could survive the freezing temperature up to 4 months. These results are supported by that obtained by Iturriaga et al., 2002 who found that Listeria monocytogenes and other bacterial strains could survive at freezing temperature for more than 14 months, while Bacillus cereus could not be detected at first month. These findings can be clarified by data obtained by Nogueira et al., 2003 who found that, citrus fruits -like orange and lemonhave intrinsic antimicrobial compounds which could inhibit the growth of 
certain types of bacteria, so Bacillus cereus could not survive this stress factor together with the freezing temperature stress which led to destruction of its living cells, while in case of Listeria monocytogenes; its own characteristic which enable it to survive low temperatures was the reason for finding it up to 4 months. The two pathogens in groups (B and $C$ ) could not be detected after 7 days of storage (Table 5).

Table (5): Effect of different surface treatments of orange on Bacillus cereus and Listeria monocytogenes count (log) at Freezer (18Co: -20Co) for different storage periods and incidence of injured bacteria

\begin{tabular}{|c|c|c|c|c|c|c|c|}
\hline \multicolumn{2}{|c|}{ Orange } & \multicolumn{9}{|c|}{ Freezer -18C-: -20C- } \\
\cline { 3 - 9 } \multicolumn{2}{|c|}{} & \multicolumn{2}{|c|}{ A } & \multicolumn{2}{c|}{ B } & \multicolumn{2}{c|}{ C } \\
\cline { 3 - 9 } & B.c & L.m & B.c & L.m & B.c & L.m \\
\hline \multirow{2}{*}{0 Day } & count & 6.60 & 6.60 & - & - & 3.48 & - \\
\cline { 2 - 9 } & injured & D & D & D & D & D & D \\
\hline \multirow{2}{*}{7 Day } & count & - & 1.60 & - & - & - & - \\
\cline { 2 - 9 } & injured & D & D & ND & ND & ND & ND \\
\hline \multirow{2}{*}{1 Month } & count & - & 1.70 & - & - & - & - \\
\cline { 2 - 9 } & injured & ND & D & ND & ND & ND & ND \\
\hline \multirow{2}{*}{2 Month } & count & - & 1.60 & - & - & - & - \\
\cline { 2 - 9 } & injured & ND & D & ND & ND & ND & ND \\
\hline \multirow{2}{*}{4 Month } & count & - & 1.60 & - & - & - & - \\
\cline { 2 - 9 } & injured & ND & D & ND & ND & ND & ND \\
\hline \multirow{2}{*}{6 Month } & count & - & - & - & - & - & - \\
\cline { 2 - 9 } & injured & ND & ND & ND & ND & ND & ND \\
\hline
\end{tabular}

This finding is supported by that obtained by Lin et al., (2002) Venkitanarayanan et al., (2002), Ukuku et al., (2004) and Alvarado et al., (2007) who raise the strong and reliable antimicrobial effect of lactic acid and hydrogen peroxide on several pathogenic bacteria. These findings explain the findings obtained from tables 8, 11 and 14 .

At room temperature, the zero time treatment was insufficient to injure all Bacillus cereus and Listeria monocytogenes which is clear with their positive results in counting and detection of injured cells while treatment $(C$ group) (Lactic acid: $\mathrm{H}_{2} \mathrm{O}_{2}$ 1.5: 2.0) could slightly decrease one log count of Bacillus cereus on the $1^{\text {st }}$ day and Listeria monocytogenes in zero time - and this may be due to the nature of the skin if the green beans which enable the penetration of the pathogen away from the effect of the treatments. By the end of the $1^{\text {st }}$ week of storage, all samples were spoiled while injured bacteria were detected in green beans (Table 6 ). These findings are supported by that elaborated by Farber et al., (1998) who found that, the storage of fresh vegetables at room temperature caused the increase in number of the bacterial flora causing utilization of all the nutrients of the substrate which led to spoilage of it.

Table (6): Effect of different surface treatments of green beans on Bacillus cereus and Listeria monocytogenes count (log) at room temperature for different storage periods and incidence of injured bacteria 
Radwan, U. M. M. et al.

\begin{tabular}{|c|c|c|c|c|c|c|c|}
\hline \multirow{2}{*}{ Green Beans } & \multicolumn{6}{|c|}{ Rom. Temperature } \\
\cline { 3 - 9 } \multicolumn{2}{|c|}{} & \multicolumn{2}{|c|}{ A } & \multicolumn{2}{c|}{ B } & \multicolumn{2}{c|}{ C } \\
\cline { 3 - 9 } & B.c & L.m & B.c & L.m & B.c & L.m \\
\hline \multirow{2}{*}{ 0 Day } & count & 6.28 & 6.90 & 5.78 & 6.38 & 5.48 & 4.48 \\
\cline { 2 - 9 } & injured & D & D & D & D & D & D \\
\hline \multirow{2}{*}{ 1 Day } & count & 5.78 & 6.84 & 6.26 & 6.20 & 5.45 & 4.48 \\
\cline { 2 - 9 } & injured & D & D & D & D & D & D \\
\hline \multirow{2}{*}{ 3 Day } & count & 5.48 & 6.80 & 6.23 & 6.30 & 4.95 & 5.18 \\
\cline { 2 - 9 } & injured & D & D & D & D & D & D \\
\hline \multirow{2}{*}{7 Day } & count & Spoilage & Spoilage & Spoilage & Spoilage & Spoilage & Spoilage \\
\cline { 2 - 9 } & injured & D & D & ND & ND & D & D \\
\hline
\end{tabular}

Table (7): Effect of different surface treatments of green beans on Bacillus cereus and Listeria monocytogenes count (log) at refrigerator (+5C: $\left.+8 C^{\circ}\right)$ for different storage periods and incidence of injured bacteria.

\begin{tabular}{|c|c|c|c|c|c|c|c|}
\hline \multirow{3}{*}{\multicolumn{2}{|c|}{ Green Beans }} & \multicolumn{6}{|c|}{ Refrigerator $+5 \mathrm{C}^{\circ}:=8 \mathrm{C}^{\circ}$} \\
\hline & & \multicolumn{2}{|c|}{$\mathbf{A}$} & \multicolumn{2}{|c|}{ B } & \multicolumn{2}{|c|}{$\mathbf{C}$} \\
\hline & & B.c & L.m & B.c & L.m & B.c & L.m \\
\hline \multirow{2}{*}{0 Day } & count & 6.25 & 6.88 & 5.59 & 5.14 & 5.48 & 4.48 \\
\hline & injured & $\mathrm{D}$ & $\mathrm{D}$ & D & D & D & D \\
\hline \multirow{2}{*}{1 Day } & count & 6.17 & 6.30 & 5.04 & 3.60 & 5.30 & 3.30 \\
\hline & injured & $\mathrm{D}$ & $\mathrm{D}$ & $\mathrm{D}$ & $\mathrm{D}$ & $\mathrm{D}$ & $\mathrm{D}$ \\
\hline \multirow{2}{*}{3 Day } & count & 6.04 & 5.43 & 4.85 & 3.60 & 5.08 & 3.00 \\
\hline & injured & $\mathrm{D}$ & $\mathrm{D}$ & $\mathrm{D}$ & $\mathrm{D}$ & $\mathrm{D}$ & $\mathrm{D}$ \\
\hline \multirow{2}{*}{7 Day } & count & 5.48 & 5.65 & 4.53 & 4.60 & 5.00 & 3.00 \\
\hline & injured & $\mathrm{D}$ & $\mathrm{D}$ & $\mathrm{D}$ & D & D & $\mathrm{D}$ \\
\hline
\end{tabular}

Table (8): Effect of different surface treatments of Green Beans on Bacillus cereus and Listeria monocytogenes count (log) at Freezer (-18Co: -20Co) for different storage periods and incidence of injured bacteria.

\begin{tabular}{|c|c|c|c|c|c|c|c|}
\hline \multirow{3}{*}{\multicolumn{2}{|c|}{ Green Beans }} & \multicolumn{6}{|c|}{ Freezer -18Co: - $20 C^{\circ}$} \\
\hline & & \multicolumn{2}{|c|}{$\mathbf{A}$} & \multicolumn{2}{|c|}{ B } & \multicolumn{2}{|c|}{ C } \\
\hline & & B.c & L.m & B.c & L.m & B.c & L.m \\
\hline \multirow{2}{*}{0 Day } & count & 6.23 & 6.82 & 5.50 & 4.60 & 5.48 & 4.48 \\
\hline & injured & $\mathrm{D}$ & $\mathrm{D}$ & $\mathrm{D}$ & $\mathrm{D}$ & $\bar{D}$ & $\mathrm{D}$ \\
\hline \multirow[b]{2}{*}{7 Day } & count & 4.95 & 5.08 & 4.50 & 3.90 & 5.00 & 2.48 \\
\hline & injured & D & D & D & D & D & ND \\
\hline \multirow{2}{*}{1 Month } & count & 4.70 & 4.70 & 3.84 & 1.60 & 4.50 & 1.78 \\
\hline & injured & $\mathrm{D}$ & $\mathrm{D}$ & $\mathrm{D}$ & ND & $\mathrm{D}$ & ND \\
\hline \multirow{2}{*}{2 Month } & count & 4.65 & 4.61 & 3.76 & - & 4.14 & - \\
\hline & injured & $\mathrm{D}$ & D & $\mathrm{D}$ & ND & $\mathrm{D}$ & ND \\
\hline \multirow{2}{*}{4 Month } & count & 4.30 & 3.49 & 3.66 & - & 3.34 & - \\
\hline & injured & $\mathrm{D}$ & D & D & ND & D & ND \\
\hline \multirow{2}{*}{6 Month } & count & 3.65 & 3.28 & 2.77 & - & 2.17 & - \\
\hline & injured & $\bar{D}$ & $\mathrm{D}$ & $\mathrm{D}$ & ND & $\mathrm{D}$ & ND \\
\hline
\end{tabular}

Table (9): Effect of different surface treatments of guava on Bacillus cereus and Listeria monocytogenes count (log) at room temperature for different storage periods and incidence of injured bacteria. 
J. Agric. Sci. Mansoura Univ., 34 (6), June, 2009

\begin{tabular}{|c|c|c|c|c|c|c|c|}
\hline \multicolumn{2}{|c|}{ Cuava } & \multicolumn{9}{c|}{ Room Temperature } \\
\cline { 3 - 9 } \multicolumn{2}{|c|}{} & \multicolumn{2}{|c|}{ A } & \multicolumn{2}{c|}{ B } & \multicolumn{2}{c|}{ C } \\
\cline { 3 - 9 } & B.c & L.m & B.c & L.m & B.c & L.m \\
\hline \multirow{2}{*}{0 Day } & count & 6.60 & 6.60 & - & - & 3.60 & 1.00 \\
\cline { 2 - 9 } & injured & D & D & D & D & D & D \\
\hline \multirow{2}{*}{1 Day } & count & 3.70 & 2.30 & - & - & - & - \\
\cline { 2 - 9 } & injured & D & D & D & D & D & D \\
\hline \multirow{2}{*}{3 Day } & count & 2.00 & - & - & - & - & - \\
\cline { 2 - 9 } & injured & D & D & ND & ND & D & D \\
\hline \multirow{2}{*}{7 Day } & Count & - & - & - & - & - & - \\
\cline { 2 - 9 } & injured & ND & ND & ND & ND & ND & ND \\
\hline
\end{tabular}

Table (10): Effect of different surface treatments of guava on Bacillus cereus and Listeria monocytogenes count (log) at refrigerator (+5Co: $\left.+8 C^{\circ}\right)$ for different storage periods and incidence of injured bacteria.

\begin{tabular}{|c|c|c|c|c|c|c|c|}
\hline \multicolumn{2}{|c|}{ Guava } & \multicolumn{6}{c|}{ Refrigerator $+5 C^{\circ}:+8 C^{\circ}$} \\
\cline { 3 - 9 } \multicolumn{2}{|c|}{} & \multicolumn{2}{|c|}{ A } & \multicolumn{2}{c|}{ B } & \multicolumn{2}{c|}{ C } \\
\cline { 3 - 9 } & B.c & L.m & B.c & L.m & B.c & L.m \\
\hline \multirow{2}{*}{0 Day } & count & 6.60 & 6.60 & - & - & 4.11 & - \\
\cline { 2 - 9 } & injured & D & D & D & D & D & D \\
\hline \multirow{2}{*}{1 Day } & count & 3.60 & 2.70 & - & - & - & 1.30 \\
\cline { 2 - 9 } & injured & D & D & D & D & D & D \\
\hline \multirow{2}{*}{3 Day } & count & 2.11 & 2.89 & - & - & - & - \\
\cline { 2 - 9 } & injured & D & D & ND & ND & ND & ND \\
\hline \multirow{2}{*}{7 Day } & count & - & 2.64 & - & - & - & - \\
\cline { 2 - 9 } & injured & D & D & ND & ND & ND & ND \\
\hline
\end{tabular}

Table (11): Effect of different surface treatments of guava on Bacillus cereus and Listeria monocytogenes count $(\log )$ at freezer (18Co: -20Co) for different storage periods and incidence of injured bacteria.

\begin{tabular}{|c|c|c|c|c|c|c|c|}
\hline \multicolumn{2}{|c|}{ Guava } & \multicolumn{6}{c|}{ Freezer -18C-: -20C- } \\
\cline { 3 - 9 } \multicolumn{2}{|c|}{} & \multicolumn{2}{|c|}{ A } & \multicolumn{2}{c|}{ B } & \multicolumn{2}{c|}{ C } \\
\cline { 3 - 9 } & B.c & L.m & B.c & L.m & B.c & L.m \\
\hline \multirow{2}{*}{0 Day } & count & 6.60 & 6.60 & - & - & 3.07 & - \\
\cline { 2 - 9 } & injured & D & D & D & D & D & D \\
\hline \multirow{2}{*}{7 Day } & count & - & - & - & - & - & - \\
\cline { 2 - 9 } & injured & D & D & D & ND & D & ND \\
\hline \multirow{2}{*}{1 Month } & count & - & - & - & - & - & - \\
\cline { 2 - 9 } & injured & D & ND & ND & ND & ND & ND \\
\hline \multirow{2}{*}{2 Month } & Count & - & - & - & - & - & - \\
\cline { 2 - 9 } & injured & ND & ND & ND & ND & ND & ND \\
\hline \multirow{2}{*}{4 Month } & count & - & - & - & - & - & - \\
\cline { 2 - 9 } & injured & ND & ND & ND & ND & ND & ND \\
\hline \multirow{2}{*}{6 Month } & count & - & - & - & - & - & - \\
\cline { 2 - 8 } & injured & ND & ND & ND & ND & ND & ND \\
\hline
\end{tabular}

On the $3^{\text {ed }}$ day (C group) (lactic acid: $\mathrm{H}_{2} \mathrm{O}_{2}$ 1.5: 2.0) was sufficient to injure all Bacillus cereus and Listeria monocytogenes which are clear with their negative results in counting and detection of injured cells; while 
treatment (B group) (Lactic acid: $\mathrm{H}_{2} \mathrm{O}_{2}$ 1.5: 1.5) could slightly decrease Bacillus cereus count and markedly decrease Listeria monocytogenes count. By the end of the $1^{\text {st }}$ week of storage, count of treated samples in ( $B$ and $C$ groups) was negative while injured bacteria were detected in (A group) treated Carrots (Table 12). These results are supported by that obtained by Farber et al., (1998) who found that by the end of one week storage, the carrot's bacterial load count declined more than 2 logs.

Table (12): Effect of different surface treatments of carrots on Bacillus cereus and Listeria monocytogenes count (log) at room temperature for different storage periods and incidence of injured bacteria.

\begin{tabular}{|c|c|c|c|c|c|c|c|}
\hline \multirow{2}{*}{ Carrot } & \multicolumn{8}{|c|}{ Rom. Temperature } \\
\cline { 3 - 9 } \multicolumn{2}{|c|}{} & \multicolumn{2}{|c|}{ A } & \multicolumn{2}{c|}{ B } & \multicolumn{2}{c|}{ C } \\
\cline { 3 - 9 } & B.c & L.m & B.c & L.m & B.c & L.m \\
\hline \multirow{2}{*}{0 Day } & count & 6.60 & 6.60 & 1.00 & 1.60 & 1.30 & - \\
\cline { 2 - 9 } & injured & D & D & D & D & D & D \\
\hline \multirow{2}{*}{ 1 Day } & count & 1.90 & 4.30 & - & - & - & - \\
\cline { 2 - 9 } & injured & D & D & D & D & D & D \\
\hline \multirow{2}{*}{ 3 Day } & count & 1.70 & 3.48 & - & - & - & - \\
\cline { 2 - 9 } & injured & D & D & D & ND & ND & ND \\
\hline \multirow{2}{*}{ 7 Day } & count & 1.00 & 2.30 & - & - & - & - \\
\cline { 2 - 9 } & injured & D & D & ND & ND & ND & ND \\
\hline
\end{tabular}

Storage at $+5 \mathrm{C}^{\circ}$ : $+8 \mathrm{C}^{\circ}$ could keep the Bacillus cereus and Listeria monocytogenes count in (A group) in relatively higher count than at room temperature. Also Bacillus cereus count in ( $C$ group) treated Carrots could survive longer than that at room temperature. The two pathogens were not detected in the $3^{\text {ed }}$ day in (B group) (Table 13).

Table (13): Effect of different surface treatments of carrots on Bacillus cereus and Listeria monocytogenes count (log) at Refrigerator ( $+5 \mathrm{C}^{\circ}:+8 \mathrm{C}$ ) for different storage periods and incidence of injured bacteria.

\begin{tabular}{|c|c|c|c|c|c|c|c|}
\hline \multirow{2}{*}{ Carrot } & \multicolumn{6}{c|}{ Refrigerator +5C $:+8 C^{\circ}$} \\
\cline { 3 - 9 } \multicolumn{2}{|c|}{} & \multicolumn{2}{|c|}{ A } & \multicolumn{2}{c|}{ B } & \multicolumn{2}{c|}{ C } \\
\cline { 3 - 9 } & B.c & L.m & B.c & L.m & B.c & L.m \\
\hline \multirow{2}{*}{0 Day } & Count & 6.60 & 6.60 & 1.30 & 1.48 & 1.30 & - \\
\cline { 2 - 9 } & Injured & D & D & D & D & D & D \\
\hline \multirow{2}{*}{1 Day } & Count & 3.45 & 4.43 & - & - & - & - \\
\cline { 2 - 9 } & Injured & D & D & D & D & D & ND \\
\hline \multirow{2}{*}{3 Day } & Count & 2.84 & 4.08 & - & - & - & - \\
\cline { 2 - 9 } & Injured & D & D & ND & ND & D & ND \\
\hline \multirow{2}{*}{7 Day } & Count & 2.00 & 3.08 & - & - & - & - \\
\cline { 2 - 9 } & Injured & D & D & ND & ND & ND & ND \\
\hline
\end{tabular}


Bacillus cereus and Listeria monocytogenes in the non treated Carrots (A group) could survive the freezing temperature up to the $7^{\text {th }}$ day. The two pathogens in groups ( $B$ and $C$ ) could not be detected after zero time of storage (Table 14).

Table (14): Effect of different surface treatments of carrots on Bacillus cereus and Listeria monocytogenes count (log) at freezer (-18Co: -20Co) for different storage periods and incidence of injured bacteria.

\begin{tabular}{|c|c|c|c|c|c|c|c|}
\hline \multirow{3}{*}{\multicolumn{2}{|c|}{ Carrot }} & \multicolumn{6}{|c|}{ 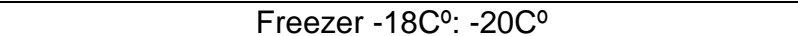 } \\
\hline & & \multicolumn{2}{|c|}{$\mathbf{A}$} & \multicolumn{2}{|c|}{ B } & \multicolumn{2}{|c|}{ C } \\
\hline & & B.c & L.m & B.C & L.m & B.c & L.m \\
\hline \multirow{2}{*}{0 Day } & count & 6.60 & 6.60 & 1.00 & 1.30 & 1.00 & - \\
\hline & injured & $\mathrm{D}$ & $\mathrm{D}$ & $\mathrm{D}$ & $\mathrm{D}$ & $\mathrm{D}$ & $\mathrm{D}$ \\
\hline \multirow{2}{*}{7 Day } & count & 2.00 & 3.11 & - & - & - & - \\
\hline & injured & $D$ & D & ND & ND & ND & ND \\
\hline \multirow{2}{*}{1 Month } & count & - & - & - & - & - & - \\
\hline & injured & ND & ND & ND & ND & ND & ND \\
\hline \multirow{2}{*}{2 Month } & count & - & - & - & - & - & - \\
\hline & injured & ND & ND & ND & ND & ND & ND \\
\hline \multirow{2}{*}{4 Month } & count & - & - & - & - & - & - \\
\hline & injured & ND & ND & ND & ND & ND & ND \\
\hline \multirow{2}{*}{6 Month } & count & - & - & - & - & - & - \\
\hline & injured & ND & ND & ND & ND & ND & ND \\
\hline
\end{tabular}

Obtained results indicate that the treatment of apple, guava, carrots and green bean with $1.5 \%$ lactic acid plus $1.5 \%$ hydrogen peroxide at $40^{\circ} \mathrm{C}$ for 15 min can effectively reduce populations of Listeria monocytogenes and Bacillus cereus by about 5.0 log CFU per fruit.

There were no marked changes in the sensory evaluation of the examined samples (odor, color, .......etc) till the end of the experiment when compared with the control samples, assuring the results obtained by McWatters et al., (2002) who conducted an extensive sensory study to determine consumer acceptance of treated fruits with the chemical wash solution. The results of this study revealed that, the sensory and qualitative characteristics of fruits were not adversely affected by the treatment, and panelists could not perceive any significant differences between the treated and the control samples.

In conclusion, the RT-PCR technique is proved to be one of the most advanced, specific and sensitive tools for estimation of the incidence of food poisoning bacteria in different kinds of food specially food of plant origin. Also, treatment with the fresh product with hydrogen peroxide and/or lactic acid in various concentrations could reduce and sometimes can completely eliminate Listeria monocytogenes and Bacillus cereus bacteria from the surface of the tested fruits and vegetables without producing any negative effects on its sensory parameters. 


\section{REFERENCES}

Abriouel, Hikmate; Omar, Nabil Ben; López, Rosario Lucas; Cañamero, Magdalena Martínez; Ortega, Elena; Gálvez, Antonio. (2007). Differentiation and Characterization by Molecular Techniques of Bacillus cereus Group Isolates from Poto Poto and Dégué, Two Traditional Cereal-Based Fermented Foods of Burkina Faso and Republic of Congo. J. Food Prot, 70 (5) 1165-1173.

Alvarado-Casillas, S.; Ibarra-Sánchez, S.; Rodríguez-García, O.; MartínezGonzáles, N.; Castillo, A. (2007). Comparison of Rinsing and Sanitizing Procedures for Reducing Bacterial Pathogens on Fresh Cantaloupes and Bell Peppers. J. of Food Protection, 70, (3): 655-660.

Choo, Euiyoung; Jang, Sung Sik; Kim, Kyumson; Lee, Kwang-Geun; Heu, Sunggi; Ryu, Sangryeol. (2007). Prevalence and genetic diversity of Bacillus cereus in Dried Red Pepper in Korea. J. Food Prot, 70(4): 917-922.

De Curtis ML, Franceschi O, De Castro N. (2002). Listeria monocytogenes in vegetables minimally processed. Arch Latinoam Nutr. 52(3):282-288.

Deener, H. G. and I. Boychuk. (1991). Species-specific detection of Listeria monocytogenes by DNA amplification. Appl. Environ. Microbiol. 57:606-609.

Farber, J. M., and P. I. Peterkin. (1991). Listeria monocytogenes, a foodborne pathogen. Microbiol. Rev. 55:476-511.

Farber JM, Wang SL, Cai Y, Zhang S. (1998). Changes in populations of Listeria monocytogenes inoculated on packaged fresh-cut vegetables. J Food Prot. 61(2):192-5.

Food and Drug Administration. (1998). Hazard analysis and critical control point (HACCP); procedures for the safe and sanitary processing and importing of juice; food labeling: warning and notice statements; labeling of juice products; nal rules. Fed. Regist. (63), 37029-37056.

Francis, G. A.; and D.O'Beirne, (2006). Isolation and pulsed-field gel electrophoresis typing of Listeria monocytogenes from modified atmosphere packaged fresh-cut vegetables collected in Ireland. J. Food Prot, 69 (10) 2524-2528.

Ghelardi E, Celandroni F, Salvetti S, Barsotti C, Baggiani A, Senesi S. (2002). Identification and characterization of toxigenic Bacillus cereus isolates responsible for two food-poisoning outbreaks. FEMS Microbiol Lett. 208(1):129-34.

Gilbert, R. J. (1992). Provisional microbiological guidelines for some ready to eat foods sampled at point of sale: notes for PHLS Food Examiners. PHLS Microbiol. Digest 9:98-99.

Hansen, B.M.; T.D. Leser and N.B. Hendriksen. (2002). Polymerase chain reaction assay for the detection of Bacillus cereus group cells. FEMS Microbiol Lett. Mar 19; 209(1):139.

Iturriaga MH, Arvizu-Medrano SM, Escartin EF. (2002). Behavior of Listeria monocytogenes in avocado pulp and processed guacamole. J Food Prot. 65(11):1745-9. 
Jay, J. M. (1996). Food-borne listeriosis, p. 478-506. In D. R. Heldman (ed.), Modern food microbiology, 5th ed. Chapman and Hall, New York, N.Y.

Lin, C.-M., S. S. Moon, M. P. Doyle, and K. H. McWatters. (2002). Inactivation of Escherichia coli O157:H7, Salmonella enterica serotype Enteritidis, and Listeria monocytogenes on lettuce by hydrogen peroxide and lactic acid and by hydrogen peroxide with mild heat. J. Food Prot. 65(8):1215-1220.

Lou, Y. and A. E. Yousef. (1996). Resistance and regeneration. Review of literature on thermal inactivation of enzymes in food. Natl. Canners Assoc. Publ. D-252. May 25.

Masafumi Ikeda, Nobuyaso Yamaguchi, katsuji tani, and Masao Nasu. (2006). Detection of food poisoning Bacteria in fresh vegetables using DNA Microarray. J Health Sci. 2006. 52(1) 36-42.

McWatters, K. H., M. P. Doyle, S. L. Walker, A. P. Rimal, and K. Venkitanarayanan. 2002. Consumer acceptance of raw apples treated with an antibacterial solution designed for home use. J. Food Prot. 65:106-110.

Nogueira MC, Oyarzabal OA and Gombas DE. (2003). Survival of Escherichia coli O157:H7, Listeria monocytogenes, and Salmonella in juice concentrates. J Food Prot. 66(9):1595-8.

Olsen, J. E., S. Aabo, W. Hill, S. Notermans, K. Wernars, P. E. Granum, T. Popovic, H. N. Rasmussen, and O. Olsvik. (1995). Probes and polymerase chain reaction of food-borne bacterial pathogens. Int. J. Food Microbiol. 28:1-78.

Sapers, G. M., and G. F. Simmons. (1998). Hydrogen peroxide disinfection of minimally processed fruits and vegetables. Food Technol. 52(2):48-52.

Sapers, G. M., R. L. Miller, and A. M. Mattrazzo. (1999). Effectiveness of sanitizing agents in inactivating Escherichia coli on Golden Delicious apples. J. Food Sci. 64:734-737.

Sapers, G. M.; Miller, R. L.; Jantschke, M.; Mattrazzo, A. M. (2000). Factors limiting the efficacy of hydrogen peroxide washes for decontamination of apples containing Escherichia coli. Journal of Food Sci., 65(3): 529532.

Ukuku DO, Pilizota V, Sapers GM. (2004). Effect of hot water and hydrogen peroxide treatments on survival of salmonella and microbial quality of whole and fresh-cut cantaloupe. J Food Prot. 67(3):432-7.

Ukuku DO. (2004). Effect of hydrogen peroxide treatment on microbial quality and appearance of whole and fresh-cut melons contaminated with Salmonella spp. Int J Food Microbiol. 95(2):137-46.

Valero, A.; Carrasco, E.; Pérez-Rodríguez, F.; García-Gimeno, R.M.; Zurera, G. (2007). J. of Food Protection, 70(3): 753-757.

Venkitanarayanan K.S.; Zhao T. and Doyle M.P. (1999). Inactivation of Escherichia coli O157:H7 by combinations of GRAS chemicals and temperature. J Food Microbiology. 16(1):75-82.

Venkitanarayanan KS, Lin CM, Bailey H, Doyle MP. (2002). Inactivation of Escherichia coli O157:H7, Salmonella enteritidis, and Listeria monocytogenes on apples, oranges, and tomatoes by lactic acid with hydrogen peroxide. J Food Prot. 65(1):100-105. 
Radwan, U. M. M. et al.

دراسة مدى تواجد ميكروبي الليستيريا مونوسيتوجينس و الباسيلس سيريس في

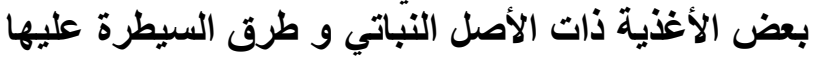

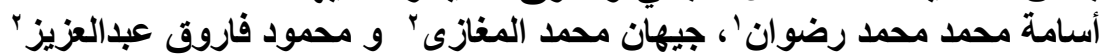

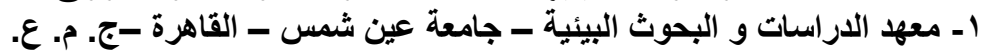

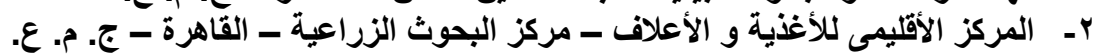

تهدف هذه الدراسة إلى إختبار طريقة عمليّة وتقيبيم فاعَّليتها فى الحد من أو تثبيط التلوث

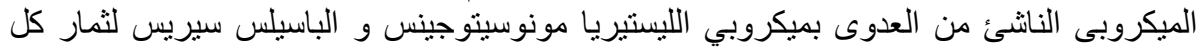

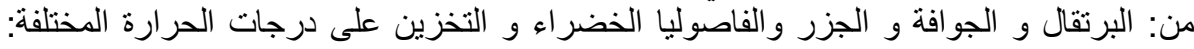

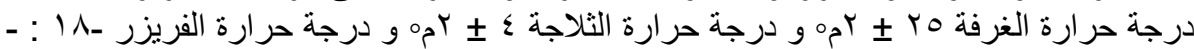

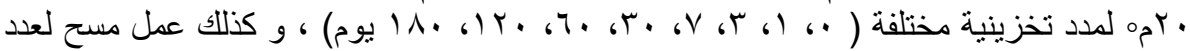

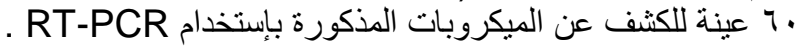

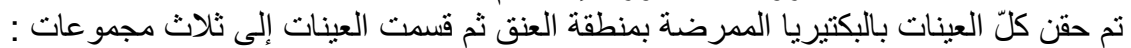

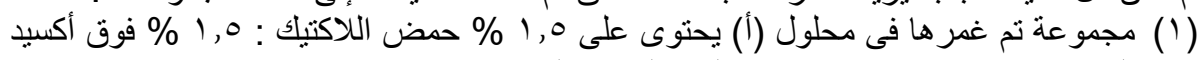

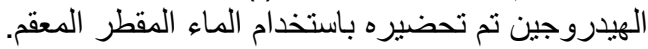

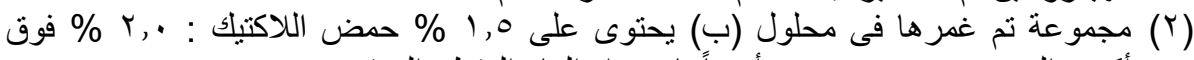

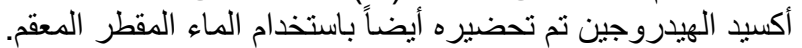

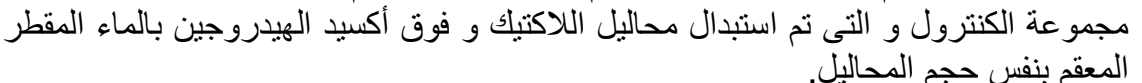

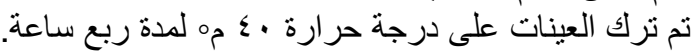

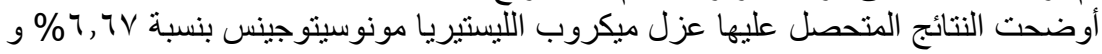

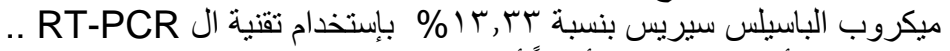

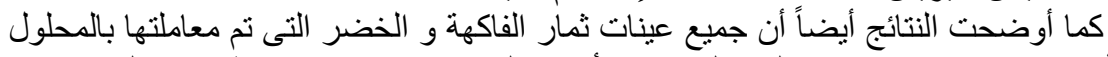

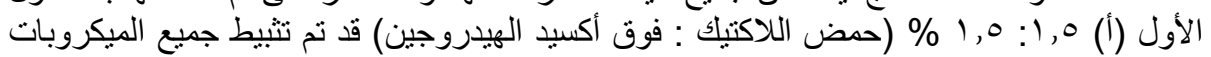

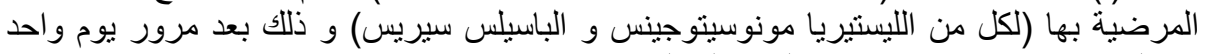

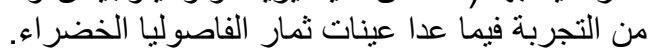

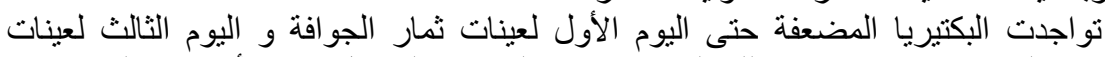

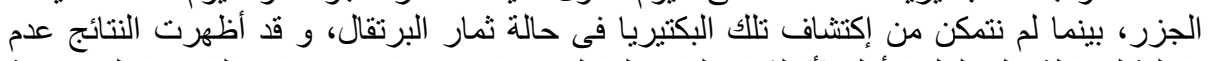

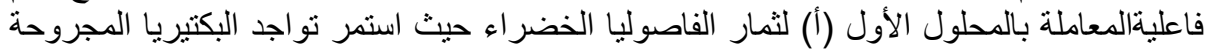

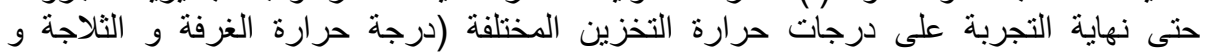

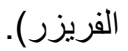

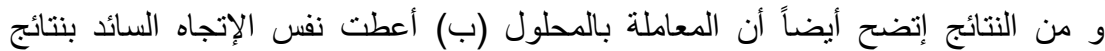

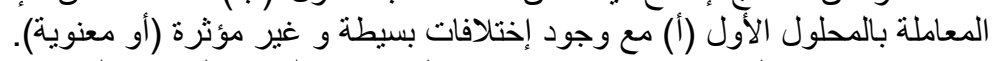

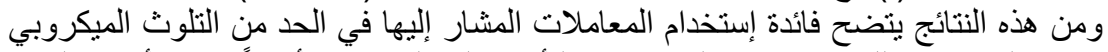

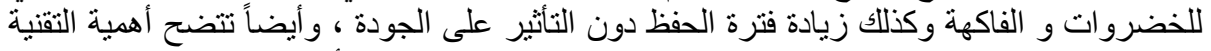

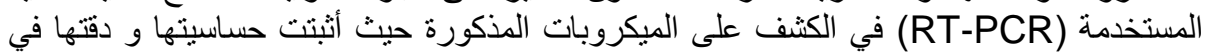
إجر اء التحليل. 